\title{
KESENJANGAN ANTARA KEBUTUHAN DAN KETERSEDIAAN GURU \\ SMA/ SMK DI KABUPATEN LANDAK PROVINSI KALIMANTAN BARAT
}

\author{
Andina Nurul Wahidah ${ }^{1}$, Edi Istiyono ${ }^{2}$ \\ ${ }^{1}$ IAIN Pontianak, ${ }^{2}$ Universitas Negeri Yogyakarta \\ e-mail: andinanurulwahidah@iainptk.ac.id ${ }^{1}$, edi_istiyono@ uny.ac.id ${ }^{2}$
}

\begin{abstract}
ABSTRAK
Kabupaten Landak merupakan salah satu daerah tergolong Terdepan, Terluar dan Tertinggal (3T) di Provinsi Kalimantan Barat yang mengalami permasalahan kekurangan guru hingga saat ini. Pemenuhan kebutuhan guru di daerah $3 \mathrm{~T}$ merupakan upaya strategis yang harus direncanakan oleh Pemerintah Daerah (Pemda) setempat. Langkah strategis tersebut dimulai dengan mengetahui seberapa besar kondisi kebutuhan guru yang dibutuhkan di setiap kecamatan dengan melakukan analisis perhitungan kebutuhan guru. Penelitian dilakukan di 4 (empat) sekolah pada kecamatan yang berbeda di wilayah Kabupaten Landak, yaitu (1) SMAN 1 Menjalin, (2) SMAN 2 Mandor, (3) SMKN 1 Ngabang dan (4) SMKN 1 Mempawah Hulu. Tujuan dilakukannya penelitian ini adalah untuk mengevaluasi kesenjangan antara kebutuhan dan ketersediaan guru SMA/SMK di Kabupaten Landak Provinsi Kalimantan Barat berdasarkan analisis perhitungan jumlah kebutuhan guru. Teknik pengumpulan data yang digunakan adalah studi dokumen yang diperoleh dari masing-masing sekolah pada tahun 2018 . Analisis perhitungan kebutuhan guru mengacu pada rumus perhitungan kebutuhan guru berdasarkan prinsip-prinsip yang diatur oleh Kementerian Pendidikan dan Kebudayaan Republik Indonesia. Hasil penelitian menunjukkan bahwa terjadi kesenjangan antara ketersediaan dan kebutuhan guru SMA/SMK di Kabupaten Landak sebesar 32\%. Analis is perhitungan kekurangan guru ini diharapkan dapat menjadi dasar bagi pemerintah setempat untuk melakukan pemetaan sebaran guru yang proporsional dan mengatasi permasalahan kekurangan guru di Kabupaten Landak.
\end{abstract}

Kata Kunci: Kesenjangan, Kebutuhan, Guru, Daerah 3T

\section{ABSTRACT}

Landak Regency is one of the Frontier, Outermost and Disadvantaged (3T) areas in the Province of West Kalimantan, which has experienced a shortage of teachers to date. Meeting the needs of teachers in the $3 T$ region is a strategic effort that must be planned by the local Regional Government (Pemda). The strategic step starts with knowing how much the conditions of the teacher's needs are needed in each district by conducting an analysis of the calculation of teacher needs. The study was conducted in 4 (four) schools in different districts in the Landak Regency, namely (1) SMAN 1 Menjalin, (2) SMAN 2 Overseer, (3) SMKN 1 Ngabang and (4) SMKN 1 Mempawah Hulu. The purpose of this research is to evaluate the gap between the needs and availability of high school / vocational high school teachers in the Landak District of West Kalimantan Province based on an analysis of the calculation of the number of teacher needs. The data collection technique used is the study of documents obtained from each school in 2018. Analysis of the calculation of teacher needs refers to the formula for 
calculating teacher needs based on principles governed by the Ministry of Education and Culture of the Republic of Indonesia. The results showed that there was a gap between the availability and needs of high school / vocational school teachers in Landak Regency by 32\%. The analysis of the calculation of teacher shortages is expected to be the basis for the local government to map proportional teacher distribution and address the problem of teacher shortages in Landak District.

Keywords: Gaps, Needs, Teachers, 3 T Regions

\section{PENDAHULUAN}

Masalah kekurangan guru merupakan salah satu masalah yang telah melanda dunia pendidikan Indonesia secara berkepanjangan, khususnya pada jenjang Sekolah Menengah Atas (SMA) dan Sekolah Menengah Kejuruan (SMK). Data statistik yang dirilis oleh Kementerian Pendidikan dan Kebudayaan Republik Indonesia (2016: 25-26) menyebutkan bahwa kekurangan guru yang terjadi pada jenjang pendidikan SMA sejumlah 160.661 orang guru dan pada jenjang SMK sejumlah 108.249 orang guru. Kondisi kekurangan guru ini masih menjadi permasalahan yang belum terselesaikan hingga saat ini.

Apabila dilihat dari segi geografis, umumnya dihadapi oleh daerah tergolong Terdepan, Terluar dan Tertinggal (3T) yang ada di Indonesia. Berdasarkan data yang dikemukakan oleh Ditjen PMPTK menyebutkan bahwa, sebanyak 21\% sekolah di perkotaan kekurangan guru, $37 \%$ sekolah di pedesaan kekurangan guru, dan 66\% sekolah di daerah 3T kekurangan guru (Tim Basics, 2014: 1). Hal ini menunjukkan bahwa kondisi kekurangan guru yang paling banyak terjadi di Indonesia adalah di daerah tergolong 3T.

Permasalahan tersebut dirasakan secara nyata di berbagai daerah di Indonesia, tanpa terkecuali di Provinsi Kalimantan Barat. Data statistik pendidikan tahun 2015/2016 menyebutkan bahwa, kekurangan guru SMA di Kalimantan Barat sejumlah 4.593 orang dan guru SMK sejumlah 1.303 orang guru (Kemendikbud, 2016: 44-48). Adanya kekurangan guru SMA/SMK sejumlah 5.896 orang guru di Kalimantan Barat ini perlu menjadi perhatian serius Pemerintah Daerah (Pemda) setempat khususnya dalam upaya pemenuhan kebutuhan guru di daerah 3T.

Penyelenggara pendidikan di daerah 3T menghadapi kompleksitas tersendiri mulai dari persoalan tentang menyediakan tenaga pendidik dan berlangsungnya pendidikan yang berkualitas terjamin hingga pada tercapainya perluasan akses dan pemerataan memperoleh layanan pendidikan (Wijayanti \& Sutapa, 2015; Suciati, 2016: 77). Kompleksitas yang dihadapi oleh daerah $3 \mathrm{~T}$ menjadi salah satu faktor penyebab kondisi pemerataan akses pendidikan di seluruh wilayah Provinsi Kalimantan Barat khususnya dalam pemenuhan kebutuhan guru di sekolah masih belum terealisasi secara optimal hingga saat ini. 
Pemerataan dan perluasan akses memperoleh layanan pendidikan sangat diperlukan khususnya bagi daerah yang tergolong 3T di Kalimantan Barat. Dalam Peraturan Presiden Nomor 131 Tahun 2015 tentang Penetapan Daerah Tertinggal tahun 2015-2019 disebutkan bahwa, daerah di Kalimantan Barat yang tergolong 3T, yaitu: (1) Kabupaten Sambas, (2) Kabupaten Bengkayang, (3) Kabupaten Landak, (4) Kabupaten Ketapang, (5) Kabupaten Sintang, (6) Kabupaten Kapuas Hulu, (7) Kabupaten Melawi dan (8) Kabupaten Kayong Utara.

Otonomi daerah yang menjadi dasar desentralisasi pendidikan di Indonesia telah memberikan kewenangan seluas-luasnya bagi Pemerintah Daerah (Pemda) untuk melakukan pengelolaan tenaga pendidik dan kependidikan sesuai dengan kebutuhan dan kemampuan daerah. Pemda dapat melakukan inovasi program guna pemenuhan kebutuhan guru di daerahnya, khususnya di daerah tergolong 3T (Tim Basics, 2014: 1). Pemda memainkan peranan penting untuk mengatasi berbagai masalah pendidikan di daerahnya masing-masing dengan menciptakan inovasi dan menjalankan program secara efektif. Salah satu daerah tertinggal di Provinsi Kalimantan Barat yang secara konsisten dan terpadu hingga saat ini melaksanakan berbagai inovasi program di bidang pendidikan untuk mengatasi masalah di daerahnya adalah Pemda Kabupaten Landak.

Kabupaten Landak merupakan salah satu daerah tertinggal di Provinsi Kalimantan Barat dan merupakan daerah yang mengalami kekurangan guru. Pada tahun 2016 disebutkan bahwa Kabupaten Landak masih mengalami kekurangan guru sebanyak 43,79\% di semua jenjang pendidikan atau sebanyak 2.904 guru yang dibutuhkan sekolah (Post Kota Pontianak, 2016).

Berdasarkan uraian permasalahan di atas, perlu dilakukan analisis dengan menghitung kesenjangan antara kebutuhan dan keterssediaan guru SMA/ SMK di Kabupaten Landak Provinsi Kalimantan Barat. Hasil penelitian ini diharapkan dapat memberi sumbangsih pemikiran untuk mewujudkan langkah-langkah strategis dalam pemenuhan kebutuhan guru sehingga pada akhirnya dapat menjadi salah satu kajian yang solutif untuk permasalahan serupa yang dihadapi daerah lainnya di Provinsi Kalimantan Barat khususnya daerah yang tergolong daerah tertinggal.

\section{Perencanaan Kebutuhan Guru}

Perencanaan kebutuhan guru merupakan salah satu upaya yang dilakukan dalam mewujudkan penataan dan pemerataan guru. Penataan dan pemerataan guru PNS telah memiliki kebijakan jelas yang diatur pemerintah dalam Peraturan Bersama Menteri Negara Pendayagunaan Aparatur Negara dan Reformasi Birokrasi, Menteri Pendidikan Nasional, Menteri Dalam Negeri, Menteri Keuangan, dan Menteri Agama Nomor 05/X/PB/2011, SPB/03/M.PAN-RB/10/2011, 48 Tahun 2011, 158/PMK.01/2011, 11 Tahun 2011 tentang 
Penataan dan Pemerataan Guru Pegawai Negeri Sipil atau biasa disebut dengan Peraturan Bersama 5 Menteri.

Perencanaan kebutuhan guru pada TK/ TKLB, SD/ SDLB, SMP/ SMPLB, SMA/ SMALB, dan SMK dilakukan oleh pejabat pembina kepegawaian provinsi/ kabupaten/ kota, sedangkan Pemerintah Provinsi berperan dalam melakukan verifikasi data guru dan analis is kebutuhan guru TK/TKLB, SD/SDLB, SMP/SMPLB, SMA/SMALB, dan SMK di setiap kabupaten/kota sesuai kewenangannya (Peraturan Bersama 5 Menteri Pasal 10; Kemendikbud, 2011:8). Untuk itu, dalam hal perencanaan kebutuhan guru di sekolah merupakan sinergisitas peran antara Pemerintah Daerah dan Pemerintah Provinsi masing-masing yang memiliki kewenangan.

Dalam dunia pendidikan, perencanaan kebutuhan guru untuk tingkat SMA dan SMK dilakukan berdasarkan laporan dari satuan pendidikan tentang jumlah guru sesuai dengan jenis guru, peserta didik, rombongan belajar, jumlah jam setiap matapelajaran yang mengacu pada struktur kurikulum, dan disesuaikan dengan jenis program yang dibuka (Kemendikbud, 2011:10).

Maka dari itu, sumber data utama dalam melakukan perencanaan kebutuhan guru berasal dari sekolah bersangkutan sehingga setiap sekolah seharusnya memiliki data perencanaan kebutuhan guru. Namun, dalam realitanya, SMA/SMK Kabupaten Landak belum memiliki data terkait perencanaan kebutuhan guru.

\section{Analisis Perhitungan Kebutuhan Guru}

Analisis perhitungan kebutuhan guru guru harus seiring dengan proyeksi jumlah siswa yang disertai dengan asumsi - asumsi tentang beban studi murid, beban mengajar guru, besar kelas, dan estimasi jumlah guru yang akan pensiun, pindah atau keluar atau yang melanjutkan pendidikan (Gaffar, 1987: 84). Lebih lanjut, Hartini (2011:102) menjelaskan bahwa dalam menghitung kebutuhan guru pada suatu lembaga atau sistem memerlukan data dasar yang mencakup hal-hal sebagai berikut:

(1) enrolment sekolah, (2) jumlah jam perminggu yang diterima murid seluruh mata pelajaran atau mata pelajaran tertentu, (3) beban mengajar penuh guru perminggu, (4) besar kelas yang dianggap efektif untuk menerima suatu mata pelajaran, (5) jumlah guru yang ada, (6) jumlah guru yang akan pensiun atau berhenti atau karena sesuatu hal yang akan meninggalkan jabatan guru, dan (7) jenis sekolah dan jenjang sekolah yang memerlukan guru.

Prinsip perhitungan kebutuhan guru pada tingkat Sekolah Menengah Atas (SMA), yaitu:

(1) Setiap rombel dalam mengikuti mata pelajaran tertentu diampu oleh 1 (satu) orang guru,

(2) Jumlah guru dihitung berdasarkan jumlah tatap muka per minggu yang terjadi di sekolah (JTM) dibagi wajib mengajar guru, (3) Jumlah tatap muka dihitung dengan cara menjumlahkanjumlah rombelper tingkat kali jumlah jam mata pelajaran per minggu per tingkat yang ada dalam struktur kurikulum, (4) Wajib mengajar yang digunakan adalah 24 
jam tatap muka per minggu, (5) Guru mata pelajaran hanya mengampu 1 (satu) jenis mata pelajaran yang sesuai dengan latar belakang pendidikan dan atau sertifikat pendidik yang dimilikinya, (6) Apabila di sekolah terdapat Iebih dari satu pendidikan agama yang diajarkan, jumlah dan jenis guru agama disesuaikan dengan kebutuhan dan peraturan yang berlaku (Kemendikbud, 2011: 19).

Prinsip perhitungan kebutuhan guru SMA dan Sekolah Menengah Kejuruan (SMK) menggunakan acuan yang sama yang dikeluarkan oleh Kemendikbud, prinsip-prinsip yang digunakan (Kemendikbud, 2011:22) sebagai berikut:

(1) Setiap rombel dalam mengik uti mata pelajaran tertentu diampu oleh 1 (satu) orang guru kecuali rombel pada mata pelajaran Dasar Kejuruan dan Kompetensi Kejuruan dibagi menjadi 2 (dua) kelompok yang masing-masing diampu oleh satu orang guru, (2) Jumlah guru dihitung berdasarkan jumlah tatap muka per minggu yang terjadi di sekolah (JTM) dibagi wajib mengajar guru, (3) Jumlah tatap muka dihitung dengan cara menjumlahkan jumlah rombel per tingkat kali jumlah jam mata pelajaran per minggu per tingkat yang ada dalam struktur kurikulum, (4) Wajib mengajar yang digunakan adalah 24 jam tatap muka per minggu, (5) Guru mata pelajaran hanya mengampu 1 (satu) jenis mata pelajaran yang sesuai dengan latar belakang pendidikan dan atau sertifikat pendidik yang dimilikinya, (6) Apabila di sekolah terdapat Iebih dari satu pendidikan agama yang diajarkan, jumlah dan jenis guru agama disesuaikan dengan kebutuhan dan peraturan yang berlaku.

Selanjutnya, rumus yang digunakan dalam menghitung kebutuhan guru disesuaikan dengan prinsip-prinsip tersebut. Dengan catatan bahwa, Jam Wajib Mengajar (JWM) disesuaikan dengan kurikulum yang berlaku dan aspek-aspek lainnya seperti mata pelajaran, jumlah siswa, dan jumlah rombel disesuaikan dengan ketentuan yang berlaku di sekolah tersebut. Secara matematis, perhitungan kebutuhan guru SMA dapat dirumuskan sebagai berikut (Kemendikbud, 2011: 19):

$$
K G=\frac{J T M}{24}=\frac{\left(M P 1 \times \sum K 1\right)+\left(M P 2 \times \sum K 2\right)+\left(M P 3 \times \sum K 3\right)}{J W M}
$$

Keterangan:

KG : Kebutuhan Guru

JTM : Jam Tatap Muka

MP : Alokasi jam mata pelajaran per minggu pada mata pelajaran tertentu di suatu tingkat

$\sum \mathrm{K}$ : Jumlah kelas pada suatu tingkat yang mengikuti pelajaran tertentu

JWM : Jam Wajib Mengajar per minggu (disesuaikan kurikulum yang digunakan oleh sekolah bersangkutan)

$1,2,3$ : Tingkat 1,2 dan 3

Rumus yang digunakan untuk menghitung perhitungan kebutuhan guru SMA relatif lebih sederhana dibandingkan perhitungan guru SMK. Untuk menghitung jumlah kebutuhan guru SMK, perhitungan guru secara umum dibedakan menjadi 2 (dua), yaitu (1) KGn/a kebutuhan guru per mata pelajaran kelompok normatif/ adaptif, dan (2) $\mathrm{KGp} / \mathrm{Kebutuhan}$ guru produktif. 
Secara matematis, perhitungan kebutuhan guru SMK menggunakan rumus sebagai berikut (Kemendikbud, 2011: 22-23):

$$
\begin{aligned}
& K G n / a=\frac{J T M}{24}=\frac{\left(M P 1 \times \sum K 1\right)+\left(M P 2 \times \sum K 2\right)+\left(M P 3 \times \sum K 3\right)}{J W M} \\
& K G p=\frac{J T M}{24}=\frac{\left(M P 1 x \sum K 1 x K P 1\right)+\left(M P 2 x \sum K 2 x K P 2\right)+\left(M P 3 x \sum K 3 x K P 3\right)}{J W M}
\end{aligned}
$$

Keterangan:

$\mathrm{KGn} / \mathrm{a}$ :Kebutuhan guru mata pelajaran normatif/ adaptif

KGp :Kebutuhan guru mata pelajaran produktif

JTM : Jam Tatap Muka

MP :Alokasi jam mata pelajaran per minggu pada mata pelajaran tertentu di suatu tingkat

$\sum \mathrm{K}$ :Jumlah kelas/rombel pada suatu tingkat yang mengikuti pelajaran produktif pada spesialisasi tertentu

JWM :Jam Wajib Mengajar per minggu (disesuaikan kurikulum yang digunakan oleh sekolah bersangkutan)

\section{1,2,3 :Tingkat 1,2 dan 3}

Penggunaan software statistik seperti microsoft excel dapat memudahkan perhitungan analisis kebutuhan guru. Dalam evaluasi ini, dipaparkan hasil analisis perhitungan kebutuhan guru untuk menjawab rumusan masalah evaluasi yang diajukan yang dapat dijadikan sebagai contoh dalam melakukan analis is perhitungan kebutuhan guru..

\section{Urgensi Pemenuhan Kebutuhan Guru}

Salah satu tugas pokok rencana strategis Depdiknas adalah pemerataan dan perluasan akses pendidikan yang dalam hal ini diarahkan melalui kebijakan rekrutmen tenaga pendidik dengan mempertimbangkan kecukupan jumlah dan kualifikasi guru di berbagai jenjang pendidikan, pemerataan penyebaran secara geografis, keahlian dan kesetaraan gender (Rusdiana, 2015:81). Pemerataan pendidikan memiliki tantangan yang cukup berat namun harus diupayakan oleh pemerintah agar masyarakat mendapat kesempatan belajar yang sama (Suryadi, 2014: 69). Evaluasi ini menekankan urgensi pemerataan pendidikan secara spesifik yaitu upaya Pemda dalam pemenuhan kebutuhan guru di daerah tertinggal.

Pemenuhan kebutuhan guru merupakan salah satu upaya dalam mewujudkan pemerataan dan perluasan pendidikan yang berkeadilan dan perluasan kesempatan belajar bagi setiap anak (Hakim, 2016: 62). Dari sejumlah studi ditunjukkan bahwa perluasan pendidikan yang tidak berkeadlian memberikan dampak buruk terhadap persebaran mutu yang tidak seimbang sehingga dibutuhkan pemerataan aktif yang mampu memberi kesamaan dan kesempatan terhadap murid agar memperoleh hasil belajar setinggi-tingginya (Mujahidun, 2016:44). Aspek 
pemerataan pendidikan pada pendidikan menengah masih menghadapi masalah cukup serius bahkan dibangdingkan pada jenjang pendidikan lainnya.

Untuk itu, dapat disimpulkan bahwa konsep pemerataan pendidikan menengah telah digaungkan sejak lama dan menjadi salah satu kebijakan yang terus diupayakan pemerintah. Pemerataan pendidikan di daerah tertinggal saat ini menuntut perwujudan pemenuhan kebutuhan guru di sekolah yang masih belum dapat terealisasikan optimal karena berbagai keterbatasan. Mengingat urgensi pemenuhan kebutuhan guru sebagai salah satu upaya pemerataan pendidikan, maka pemerintah pusat dan daerah harus sinergi dalam mengimplementasikan kebijakan agar daerah tertinggal tidak lagi dimarginalkan dalam hal penyediaan guru.

\section{PEMBAHASAN}

Distribusi guru yang belum merata apabila dilihat dari segi kuantitas, rasio guru dan siswa rata-rata 1 banding 16 di setiap tingkat pendidikan (Ferdiansyah, 2019: 12). Permasalahan kekurangan guru yang lebih kompleks di Indonesia terjadi di daerah tertinggal, di Indonesia daerah tertinggal umumnya dicirikan dengan letak geografisnya relatif terpencil, atau wilayah-wilayah yang miskin sumber daya alam, atau rawan bencana alam dan relatif kurang berkembang dibandingkan dengan daerah lain dalam skala nasional (Bappenas, 2004). Kekurangan guru di daerah tertinggal umumnya disebabkan karena ketidakcukupan guru yang bersedia dan berkomitmen untuk mengajar atau ditempatkan di daerah tertinggal. Penyebab kekurangan guru terletak pada pendistribusian guru (Subair \& Talabi, 2015:32). Menurut Makinde (2010), sekolah di daerah pedesaan tidak menerima kuota guru terlatih sementara banyak guru di daerah pedesaan sering melakukan transfer ke kota. Selain itu, Lunenburg \& Ornstein (2012) juga menguatkan bahwa banyak guru tidak mau mengajar di daerah pedesaan terutama di sekolah dengan siswa yang berasal dari kondisi ekonomi rendah seperti halnya di daerah tertinggal.

Rencana Strategis (Renstra) Kemendikbud Republik Indonesia tahun 2015-2019 menyebutkan bahwa pemenuhan kekurangan guru di daerah tertinggal akan sulit terlaksana karena terbatasnya ketersediaan guru. Untuk itu, penyediaan Sumber Daya Manusia (SDM) untuk mengatasi kekurangan guru merupakan bentuk perencanaan jangka panjang yang dapat menjadi solusi.

Data pokok sekolah terkait kondisi SMA/SMK di Kabupaten Landak diperoleh dari hasil dokumentasi yang akan menjadi acuan dalam melakukan perhitungan kebutuhan guru pada bagian analisis. Kondisi SMA/SMK di Kabupaten Landak tahun 2017/2018 diolah ke dalam Tabel 1.

Tabel 1. Kondisi SMA/SMK di Kabupaten Landak 


\begin{tabular}{|c|c|c|c|c|c|}
\hline \multirow[b]{2}{*}{ No } & \multirow{2}{*}{ Nama Sekolah } & \multirow{2}{*}{ Kelas } & \multirow{2}{*}{$\begin{array}{l}\text { Jumlah } \\
\text { Rombel }\end{array}$} & \multicolumn{2}{|c|}{ Jumlah Guru } \\
\hline & & & & PNS & Honorer dan GTT \\
\hline \multirow{3}{*}{1} & \multirow{3}{*}{ SMAN 1 Menjalin } & $X$ & 8 & \multirow{3}{*}{20} & \multirow{3}{*}{14} \\
\hline & & XI & 7 & & \\
\hline & & XII & 6 & & \\
\hline \multirow{3}{*}{2} & \multirow{3}{*}{ SMAN 2 Mandor } & $\mathrm{X}$ & 3 & \multirow{3}{*}{11} & \multirow{3}{*}{12} \\
\hline & & $\mathrm{XI}$ & 3 & & \\
\hline & & XII & 3 & & \\
\hline \multirow{3}{*}{3} & \multirow{3}{*}{ SMKN 1 Ngabang } & $\mathrm{X}$ & 12 & \multirow{3}{*}{31} & \multirow{3}{*}{43} \\
\hline & & XI & 11 & & \\
\hline & & XII & 11 & & \\
\hline \multirow{3}{*}{4} & \multirow{3}{*}{$\begin{array}{l}\text { SMKN } 1 \\
\text { Mempawah Hulu }\end{array}$} & $\mathrm{X}$ & 5 & \multirow{3}{*}{8} & \multirow{3}{*}{37} \\
\hline & & XI & 10 & & \\
\hline & & XII & 7 & & \\
\hline \multicolumn{4}{|c|}{ Jumlah (orang) } & 70 & 106 \\
\hline \multicolumn{4}{|c|}{ Persentase $(\%)$} & 40 & 60 \\
\hline
\end{tabular}

Berdasarkan Tabel 1, dapat diketahui jumlah rombel (rombongan belajar), kurikulum yang digunakan serta jumlah guru berdasarkan status kepegawaiannya di 4 (empat) SMA/SMK yang menjadi sampel evaluasi program ini. Jumlah rombel di setiap sekolah berbeda-beda, Tabel 1 menunjukkan bahwa rombel pada tingkat SMK lebih banyak dibandingkan pada tingkat SMA.

Selain itu, dilihat dari segi struktur kurikulum yang digunakan, masih ada sekolah yang menerapkan Kurikulum Tingkat Satuan Pendidikan (KTSP) yaitu SMA Negeri 1 Menjalin pada jenjang kelas XII dan SMK Negeri 1 Mempawah Hulu pada jenjang kelas X, XI dan XII, sedangkan SMA Negeri 2 Mandor dan SMK Negeri 1 Ngabang telah sepenuhnya menerapkan kurikulum 2013. Analisis lebih lanjut untuk menghitung kebutuhan guru akan mengacu pada struktur kurikulum yang digunakan. Kondisi ketersediaan guru SMA/ SMK di Kabupaten Landak berdasarkan status kepegawaiannya diolah dalam Gambar 1. 


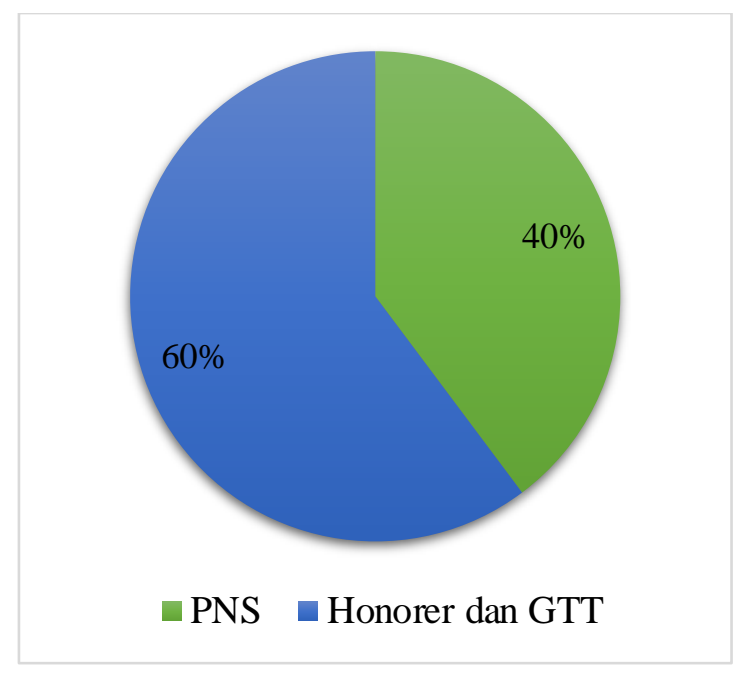

Gambar 1. Ketersediaan Guru SMA/SMK di Kabupaten Landak (Berdasarkan Status Kepegawaiannya)

Berdasarkan Gambar 1, diketahui bahwa sebagian besar ketersediaan guru SMA/SMK di Kabupaten Landak didominasi oleh guru berstatus non PNS yaitu guru honorer sekolah dan Guru Tidak Tetap (GTT) sebesar 60\%. Persentase ini cukup besar apabila dibandingkan jumlah guru berstatus Pegawai Negeri Sipil (PNS) yang hanya sebesar 40\%. Hal ini menunjukkan bahwa penempatan honorer dan GTT sangat membantu memenuhi ketersediaan guru di Kabupaten Landak yang tidak bisa dipenuhi oleh guru berstatus PNS saja. Pada bagian hasil analisis, akan dilakukan perhitungan jumlah kebutuhan guru SMA/SMK di Kabupaten Landak. Hal ini dilakukan untuk melihat kesenjangan yang ada antara jumlah ketersediaan guru dengan jumlah kebutuhan guru SMA/SMK di Kabupaten Landak.

Peneliti telah melakukan analisis perhitungan kebutuhan guru SMA/SMK di Kabupaten Landak berdasarkan data pokok yang diperoleh dari sekolah yang terpilih sebagai sampel. Hasil perhitungan tersebut kemudian dibandingkan dengan jumlah ketersediaan guru yanga ada, sehingga ditemukan kesenjangan. Hasil analisis kondisi kesenjangan antara kebutuhan dan ketersediaan guru SMA/SMK di Kabupaten Landak disajikan dalam Tabel 2.

Tabel 2. Kesenjangan antara Ketersediaan dan Kebutuhan Guru SMA/SMK di Kabupaten Landak

\begin{tabular}{|c|l|c|c|}
\hline No & \multicolumn{1}{|c|}{ Nama Sekolah } & $\begin{array}{c}\text { Kebutuhan Guru } \\
\text { (orang) }\end{array}$ & $\begin{array}{c}\text { Ketersediaan Guru } \\
\text { (orang) }\end{array}$ \\
\hline 1 & SMAN 1 Menjalin & 64 & 34 \\
\hline 2 & SMAN 2 Mandor & 32 & 23 \\
\hline 3 & SMKN 1 Ngabang & 88 & 74 \\
\hline 4 & SMKN 1 Mempawah Hulu & 75 & 45 \\
\hline
\end{tabular}




\begin{tabular}{|c|c|}
\hline Jumlah (orang) & 259 \\
\hline Kesenjangan Jumlah Guru & \multicolumn{2}{|c|}{876} \\
\hline
\end{tabular}

Tabel 2 menunjukkan adanya kesenjangan antara ketersediaan dan kebutuhan guru SMA/SMK di Kabupaten Landak tahun 2017/2018. Kesenjangan yang terjadi berupa kondisi kekurangan guru dimana guru yang tersedia jumlahnya lebih sedikit dibandingkan jumlah kebutuhan guru (Kemendikbud, 2011: 5). Berdasarkan Tabel 2, dapat diketahui bahwa jumlah kebutuhan guru SMA/SMK di Kabupaten Landak adalah 259 orang, sedangkan jumlah guru yang tersedia hanya sebesar 176 orang. Hal ini menunjukkan kondisi kekurangan guru SMA/SMK di Kabupaten Landak tahun 2017/2018 sejumlah 83 orang. Kesenjangan yang terjadi di 4 (empat) SMA/SMK yang terpilih sebagai sampel evaluasi ini memiliki persentase kesenjangan berbeda-beda. Kondisi kekurangan guru yang terjadi di SMA/SMK Kabupaten Landak tahun berdasarkan analisis perhitungan jumlah kebutuhan guru disajikan dalam Gambar 2.

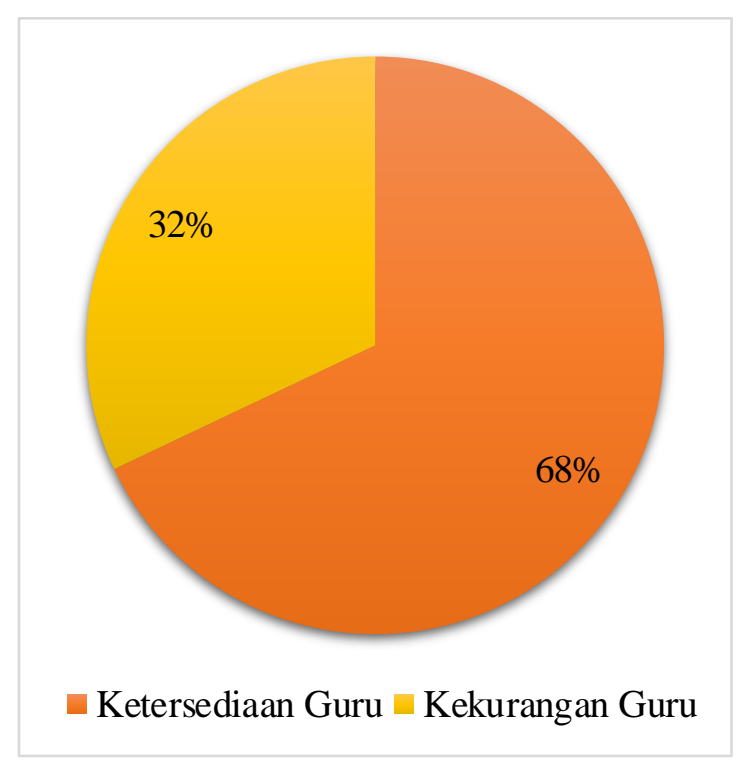

Gambar 2. Kondisi Kekurangan Guru SMA/SMK di Kabupaten Landak

Gambar 2 menegaskan bahwa masih terjadi kondisi kekurangan guru SMA/SMK di Kabupaten Landak. Kondisi kekurangan guru dengan persentase sebesar 32\% merupakan besaran persentase yang cukup memprihatinkan dan perlu segera diatasi. Sebagaimana diketahui bahwa telah banyak inovasi yang dilakukan pemerintah setempat khususnya di bidang pendidikan, namun dapat disimpulkan bahwa masih terjadi kesenjangan antara ketersediaan dan kebutuhan guru di lapangan. Hal ini menunjukkan bahwa Pemerintah Republik Indonesia khususnya Pemerintah Daerah (Pemda) Kabupaten Landak perlu 
menemukan langkah-langkah strategis untuk mengatasi kekurangan guru agar dapat mewujudkan pemenuhan kebutuhan guru di daerah.

Sejak dikeluarkannya Peraturan Bersama 5 Menteri berupa Peraturan Bersama Menteri Negara Pendayagunaan Aparatur Negara dan Reformasi Birokrasi, Menteri Pendidikan Nasional, Menteri Dalam Negeri, Menteri Keuangan, dan Menteri Agama Nomor 05/X/PB/2011, SPB/03/M.PAN-RB/10/2011, 48 Tahun 2011, 158/PMK.01/2011, 11 pada tahun 2011 semakin ditegaskan bahwa penataan dan pemerataan guru merupakan prioritas yang harus segera direalisasikan oleh setiap daerah. Peraturan Bersama 5 Menteri tersebut dibuat utuk menjamin pemerataan guru antar satuan pendidikan, antar jenjang, dan antar jenis pendidikan, antar kabupaten, antar kota, dan antar provinsi serta dalam upaya mewujudkan peningkatan dan pemerataan mutu pendidikan formal secara nasional dan pencapaian tujuan pendidikan nasional (Kemendikbud, 2011:4).

Persoalan pemerataan guru khususnya di daerah tertinggal merupakan persoalan kompleks yang membutuhkan sinergisitas peran dari seluruh elemen, mulai dari aparatur pemerintahan hingga masyarakat.

Pemenuhan kebutuhan guru di daerah yang tergolong daerah tertinggal memerlukan langkah-langkah strategis yang harus dilakukan Pemerintah Daerah setempat. Distribusi guru yang merata perlu diusahakan karena merupakan salah satu dari berbagai variabel penentu kualitas pendidikan (Wahyuni, 2019: 16).

Permasalahan terkait lemahnya sistem informasi data kependidikan merupakan salah satu penyebab utama distribusi guru yang masih belum merata di Indonesia (Kemendikbud, 2016: 87). Untuk itu, langkah pertama yang harus dilakukan oleh Pemerintah Daerah adalah menyediakan data kondisi guru di daerahnya.

Permasalahan kekurangan guru bukanlah permasalahan eksklusif yang terjadi pada sistem pendidikan di Indonesia saja. Permasalahan ini telah menjadi fenomena dunia yang terjadi sejak lama, laporan UNESCO menunjukkan bahwa pada tahun 1980, dunia dengan jumlah penduduk sebesar 5,5 miliar hanya memiliki 40 juta guru dalam profesi mengajar yang memberikan rata-rata satu guru per 112 penduduk (Subair \& Talabi, 2015: 32). Kekurangan guru terjadi di negara maju maupun berkembang, namun kondisi yang cukup memprihatinkan terjadi di sebagian besar negara berkembang (Fyfe, 2017:1). Indonesia sebagai salah satu negara berkembang di dunia telah merasakan permasalahan kekurangan guru sejak lama dan masih belum sepenuhnya teratasi hingga saat ini.

Ketidakcukupan guru yang bersedia dan berkomitmen untuk ditempatkan mengajar di daerah tertinggal menjadi tolak ukur utama untuk mencari solusi agar terwujudnya pemenuhan kebutuhan guru. Besaran atau tingkat gaji yang diberikan kepada guru di daerah tertinggal 
menjadi hal penting untuk diperhatikan mengingat bahwa perubahan dalam tingkat gaji dapat memengaruhi distribusi kualifikasi guru (Adamson \& Hammond, 2012: 30). Selain itu, dalam sebuah studi yang dilakukan oleh Loeb \& Reininger (2004) menyebutkan adanya kecendrungan preferensi yaitu para guru lebih memilih untuk mengajar di komunitas yang serupa dengan tempat di mana mereka tumbuh. Hal ini dalam demografi guru nasional merupakan tantangan untuk merekrut guru dari daerah sekolah perkotaan ke daerah pedesaan. Untuk itu, upaya perekrutan guru dari perkotaan untuk mengajar di daerah tertinggal bukanlah solusi konkrit yang dapat dilakukan.

Berdasarkan analisis tersebut, maka dapat disimpulkan bahwa adanya kecendrungan preferensi menyebabkan solusi perekrutan guru yang lebih efektif untuk memenuhi kebutuhan guru di Kabupaten Landak adalah dengan melakukan perekrutan tenaga guru dari warga daerah setempat. Untuk itu, pemenuhan kebutuhan guru di daerah tertinggal merupakan upaya strategis yang harus direncanakan oleh Pemerintah Daerah (Pemda) setempat, yang dalam hal ini adalah Pemerintah Kabupaten Landak.

Langkah strategis tersebut dimulai dengan mengetahui seberapa besar kondisi kebutuhan guru yang dibutuhkan di setiap kecamatan dengan melakukan analisis perhitungan kebutuhan guru. Setelah data hasil analisis kebutuhan guru diperoleh, Pemda Kabupaten Landak perlu melakukan pemetaan untuk mengetahui kecamatan yang mengalami kondisi kekurangan guru terbesar hingga terkecil sehingga dapat mengetahui sekolah yang memiliki prioritas untuk dipenuhi.

Maka, perhitungan analisis kebutuhan guru menjadi hal dasar yang harus dimiliki oleh Pemda Kabupaten Landak. Hasil penelitian ini diharapkan dapat menjadi salah satu gambaran untuk melakukan analisis perhitungan kebutuhan guru SMA/ SMK di Kabupaten Landak. Di era otonomi daerah saat ini, pemerintah harus bekerja ekstra untuk pembangunan daerahnya.

\section{KESIMPULAN}

Distribusi guru proporsional merupakan kebutuhan prioritas dunia pendidikan Indonesia khususnya pada sekolah yang terletak di daerah 3T. Langkah awal yang harus dilakukan pemerintah setempat adalah menganalisis kebutuhan guru di daerahnya dengan menghitung kesenjangan antara ketersediaan dan kebutuhan guru. Kondisi ketersediaan guru SMA/ SMK di Kabupaten Landak sejumlah 176 orang dengan persentase sebesar 68\%, sedangkan hasil analisis perhitungan kebutuhan guru menunjukkan jumlah yang harus dipenuhi adalah 259 orang. Untuk itu, Kabupaten Landak mengalami kondisi kekurangan guru SMA/SMK sejumlah 83 orang guru dengan persentase sebesar 32\%. Maka, masih terjadi kesenjangan antara ketersediaan dan kebutuhan guru SMA/SMK di Kabupaten Landak. 


\section{DAFTAR PUSTAKA}

Adamson, F., \& Hammond, N. D. (2012). Funding disparities and the inequitable distribution of teachers: evaluating sources and solutions. United States: Education Policy Analys is Archives, 20(37) Retrieved [date], from http//epaa.asu.edu/ojs/article/view/1053.

Bappenas. (2004). Pengembangan ekonomi daerah berbasis kawasan andalan: membangun model pengelolaan dan pengembangan keterkaitan program. Info Kajian Bappenas Vol.1 No.2 Oktober 2004, Deputi Bidang Otonomi Daerah Dan Pengembangan Regional Direktorat Pengembangan Kawasan Khusus Dan Tertinggal.

Ferdiansyah. (2019). Perlu grand design penuhi kebutuhan guru. Parlementaria Edisi 170 Tahun 2019.

Fyfe,A,. (2017). The use of contract teachers in developing countries: trends and impact. Geneva: International Labour Office.

Gaffar, M. F. (1987). Perencanaan pendidikan teori dan metodologi. Jakarta: Depdikbud.

Hakim, L. (2016). Pemerataan akses pendidikan bagi rakyat sesuai dengan amanat undangundang nomor 20 tahun 2003 tentang sistem pendidikan nasional. Jurnal EduTech Volume 2 Nomor 1.

Hartini, S. (2011). Evaluasi pembelajaran. Surakarta: Qinant.

Kemendikbud Republik Indonesia. (2016). Analisis sumber daya manusia pendidikan dasar dan menengah tahun 2015/2016. Jakarta: Kementerian Pendidikan dan Kebudayaan Republik Indonesia, Pusat Data dan Statistik Pendidikan dan Kebudayaan.

Loeb, S., \& Reininger, M. (2004). Public policy and teacher labor markets: what we know and why it matters. The Education Policy Center at Michigan State University.

Lunenburg, F. C. \& Ornstein, A. C. (2012). Educational administration: concepts and practices. USA: Thompson Higher Education.

Makinde, M. A. (2010). Effective management of secondary schools: a teacher-inspector's perspective. Ibadan: Mosmak Enterprise.

Menteri Negara Pendayagunaan Aparatur Negara dan Reformasi Birokrasi, Menteri Pendidikan Nasional, Menteri Dalam Negeri, Menteri Keuangan, dan Menteri Agama. (2011). Peraturan Bersama 5 Menteri tentang Penataan dan Pemetaan Guru PNS.

Mujahidun. (2016). Pemerataan pendidikan anak bangsa: pendidikan gratis versus kapitalisme pendidikan. Jurnal Tarbiyatuna Volume 7 Nomor 1.

Post Kota Pontianak. (2016). Landak masih kekurangan guru.

Presiden Republik Indonesia (2015). Peraturan Presiden Nomor 131 Tahun 2015 tentang Penetapan Daerah Tertinggal tahun 2015-2019.

Rusdiana. (2015). Kebijakan pendidikan dari filosofi ke implementasi. Bandung: Pustaka Setia. 
Subair,T,. \& Talabi, R. (2015). Teacher shortage in nigerian schools: causes, effects and administrators coping strategies. Asia Pacific Journal of Education, Arts and Sciences, Vol. 2 No. 4, October 2015(Part II).

Suciati, A. (2016). Pengembangan model pendidikan menengah "sekolah kebangsaan "di daerah terpencil, tertinggal, terluar dan perbatasan sebagai implementasi pembelajaran pkn. Jurnal Moral Kemasyarakatan Volume 1, No.1, 76-86.

Suryadi. (2014). Pendidikan Indonesia menuju 2025, outlook: permasalahan, tantangan \& alternatif kebijakan. Bandung: Remaja Rosdakarya.

Suryosubroto. (1997). Proses belajar mengajar di sekolah. Jakarta: Rineka Cipta.

Tim Basics. (2014). Panduan penerapan praktik cerdas program guru tidak tetap daerah terpencil dan kepulauan. Jakarta: Basics.

Wahyuni, D. (2019). Permasalahan dan upaya perbaikan system zonasi dalam penerimaan peserta didik baru 2019. Info Singkat Kajian Singkat terhadap Isu Aktual dan Strategis, Volume XI Nomor 13, Pusat penelitian Badan Keahlian DPR RI.

Wijayanti, W \& Sutapa, M. (2015). Penataan dan pemerataan guru: analisis kebutuhan, ketersediaan dan kecukupan guru di kabupaten purbalingga jawa tengah. Teknodika Volume 13 Nomor 1 Maret 2015, 85-100 